\title{
Penerapan Model Rapid Application Development Pada Perancangan Sistem Informasi Jasa Pengiriman Barang
}

\author{
Lala Nilawati ${ }^{1}$, Dedeh Sulastri ${ }^{2}$, Yuyun Yuningsih ${ }^{3}$ \\ ${ }^{1}$ Universitas Bina Sarana Informatika \\ e-mail: lala.lni@bsi.ac.id \\ ${ }^{2}$ Universitas Bina Sarana Informatika \\ e-mail: dedeh@bsi.ac.id \\ ${ }^{3}$ Sekolah Tinggi Manajemen Informatika dan Komputer Nusa Mandiri \\ e-mail: yuyun.yyg@nusamandiri.ac.id
}

\begin{abstract}
Abstraksi - Perusahaan jasa pengiriman barang adalah suatu perusahaan atau badan usaha yang bergerak dibidang jasa memberikan pelayanan pengiriman barang. Berkaitan dengan kegiatan usaha yang terjadi pada perusahaan jasa, maka dibutuhkan sistem informasi manajemen yang baik yang dapat mengelola data pengiriman. Sebuah sistem informasi yang baik dan akurat akan sangat dibutuhkan seiring dengan meningkatnya kebutuhan manusia terhadap informasi yang cepat, tepat dan akurat. Pemilihan sebuah sistem perangkat lunak harus memiliki kinerja yang baik, dan tentunya tidak terlepas dari cara memilih dan menerapkan metode analisis dan perancangannya. Pada penelitian ini akan dirancang sebuah sistem pengiriman barang menggunakan Rapid Application Development (RAD), dimana penulis menganalisis sistem pengelolaan data yang terdapat dalam perusahaan, kemudian membuat suatu desain protoype yang sesuai untuk pengelolaan data tersebut agar lebih lengkap, efisien, dan mudah digunakan sebagai pengembangan dari sistem yang lama dengan menggunakan Java Script dan MySQL sebagai database nya. Selain itu dalam mendesain sistem yang diusulkan yaitu sistem informasi jasa pengiriman barang, alat bantu yang digunakan adalah menggunakan ERD (Entity Relationship Diagram) dan UML (Unified Modelling Language). Berdasarkan analisis dan penerapan sistem yang dilanjutkan dengan pengujian sistem, sistem pengiriman barang yang dirancang ini dapat mempermudah pemakai sistem dalam mengolah data, mengontrol data dan pembuatan laporan yang berhubungan dengan data pengiriman..
\end{abstract}

Kata Kunci: Rapid Application Development (RAD), Sistem Informasi, Pengiriman Barang

Abstract - Freight forwarding company is a company or business entity which is engaged in providing freight forwarding services. In connection with business activities that occur in service companies, a good management information system is needed that can manage data delivery. The availability of a good and accurate information system will be increasingly needed along with the increasing human need for information that is fast, precise and accurate. The steps needed to produce a software system so that it has good performance, of course, can not be separated from how to choose and apply the analysis and design methods. In this research, a goods delivery system will be designed using Rapid Application Development (RAD), where the authors analyze the data management system contained in the company, then create a prototype design that is suitable for data management to make it more complete, efficient, and easy to use as a development from the old system using Java Script and MySQL as its database. In addition, in designing the proposed system, which is the information system of freight forwarding services, the tools used are using ERD (Entity Relationship Diagram) and UML (Unified Modeling Language). Based on the analysis and application of the system followed by testing the system, the delivery system designed can make it easier for system users to process data, control data and prepare reports related to shipping data.

Keywords: Rapid Application Development (RAD), Information Systems, Goods Delivery

\section{PENDAHULUAN}

Perusahaan jasa pengiriman barang adalah suatu perusahaan atau badan usaha yang bergerak dibidang jasa memberikan pelayanan pengiriman barang. Suatu barang akan dikirim karena adanya suatu kebutuhan untuk memindahkan atau mengirim barang dari satu tempat ke suatu tempat lainnya. Berkaitan dengan kegiatan usaha yang terjadi pada perusahaan jasa, maka dibutuhkan sistem informasi manajemen yang baik yang dapat mengelola data pengiriman. Penelitian yang dilakukan Ratnawaty dan Gustini membahas bagaimana membangun sebuah aplikasi menggunakan metode Rapid 
Application Development (RAD) sebagai solusi pencatatan transaksi akuntansi pada PT Dana Dyaksa Loka. Berdasarkan hasil penelitian yang dilakukan, dengan adanya pembangunan aplikasi akuntansi ini, maka perusahaan akan dimudahkan untuk melakukan penyimpanan serta pemrosesan data transaksi pengiriman barang (Ratnawati \& Gustini, 2019). Sebuah sistem perangkat lunak agar memiliki kinerja yang baik, tentunya tidak terlepas dari cara memilih dan menerapkan metode analisis dan perancangannya (Kosasi \& Yuliani, 2015). Perkembangan teknologi informasi yang begitu cepat sudah pasti perlu untuk menyesuaikan sistem kerja didalam usahanya, dengan menggunakan sistem komputerisasi yang mampu mengolah data, dan menghasilkan informasi dengan cara yang efektif dan efisien (Kirlyana \& Rosyida, 2016).

Rapid Application Development (RAD) merupakan salah satu metode strategi pengembangan sistem, yang mengutamakan kecepatan pengembangan melalui keterlibatan pemakai luas dalam penggunaan suatu rangkaian konstruksi, dimana rangkaian tersebut berfungsi sebagai suatu model (prototype) sistem yang lebih efektif. Rapid Application Development (RAD) adalah salah satu metode pengembangan suatu sistem informasi dengan waktu yang relatif singkat. RAD hanya memerlukan waktu 30-90 hari dari waktu waktu normal minimal 180 hari (Noertjahyana, 2002). Kosasi dalam penelitiannya menyebutkan "Penerapan metode RAD (Rapid Application Development) dalam menghasilkan sistem perangkat lunak perniagaan elektronik untuk produk furniture secara nyata sudah dapat memberikan hasil yang maksimal" (Kosasi, 2015). Penelitian oleh Pratama, dkk menghasilkan bahwa dengan metode pengembangan RAD (Rapid Application Development) dengan tahapan Requirment Planning, Workshop Design dan Implementation, dalam pengembangan rancangan sistem informasi monitoring pajak bumi dan bangunan, menjadikan sistem jadi lebih cepat dan efisien (Pratama, Nurdiawan, \& Pramudita, 2019). Pada penelitian yang dilakukan Ramdhani dan Rusmana menyebutkan bahwa dengan menerapkan metode RAD pada pengembangan Sistem Proyek Pertunjukan di Trans Studio Bandung, mampu mempercepat pembuatan sistem (Ramdhani \& Rusmana, 2019). Suatu sistem diharapkan dapat memenuhi harapan para pemakainya, ini merupakan tujuan utama dari semua metode sistem pengembangan, tetapi dalam kenyataan nya sering kali didalam melakukan pengembangan suatu sistem tidak melibatkan para pemakai sistem secara langsung, sehingga hal ini menyebabkan sistem informasi yang dibuat jauh dari harapan pemakai yang dapat berakibat sistem tersebut walaupun dapat diterima. Salah satu manfaat Rapid Application Development (RAD) diimplementasikan, maka para pemakai bisa menjadi bagian dari keseluruhan proses pengembangan sistem, dengan bertindak sebagai pengambil keputusan pada setiap tahapan pengembangan. Penggunaan sistem informasi sangat penting untuk mendukung pengambilan keputusan manajemen (Irawan, Mustafid, \& Sugiharto, 2014). Sistem yang dirancang dengan menerapkan metode Rapid Application Development (RAD) diharapkan dan memberikan kontribusi kepada pihak menajeman.

PT. Lintasindo Dharma Sakti yang beralamat di Jl. A.M. Sangaji No, 27 A/5, Jakarta Pusat adalah sebuah perusahaan jasa ekspedisi pengiriman barang antar kota meliputi kota jakarta, kota surabaya, kota balikpapan, dan kota banjarmasin. Banyaknya paket yang di kirim maka banyak pula data barang yang harus diolah pada waktu pengiriman, yang memerlukan waktu untuk memprosesnya. Sistem yang diterapkan masih menggunakan sistem media pembukuan mulai dari data pengiriman, data pelanggan, pembuatan laporan pengiriman, sampai daftar muatan barang masih dapat menimbulkan beberapa kendala, seperti keterlambatan pengiriman, keterlambatan pelaporan dan pencarian data laporan pengiriman barang membutuhkan waktu dan proses yang lama, sehingga tingkat efektifitas dan efisiensi dari perusahaan tersebut akan berkurang. Pada penelitian ini akan dibuatkan solusi untuk mengatasi masalah diatas dengan membuat sistem pengiriman barang menggunakan Rapid Application Development (RAD), dimana penulis menganalisis sistem pengelolaan data yang terdapat dalam perusahaan, kemudian membuat suatu desain protoype yang sesuai untuk pengelolaan data tersebut agar lebih lengkap, efisien, dan mudah digunakan sebagai pengembangan dari sistem yang lama dengan menggunakan Java Script dan MySQL sebagai database nya. Rapid Application Development (RAD) menggunakan prototype untuk mempercepat suatu analisa kebutuhan dalam suatu desain sistem. Prototype adalah suatu model kerja yang mewakili kebutuhan pemakai atau suatu desain yang diusulkan untuk suatu sistem informasi. Selain itu dalam mendesain sistem yang diusulkan yaitu sistem informasi jasa pengiriman barang, alat bantu yang digunakan adalah menggunakan ERD (Entity Relationship Diagram) dan UML (Unified Modelling Language).

\section{METODOLOGI PENELITIAN}

Metode penelitian yang penulis gunakan adalah sebagai berikut:

\section{A. Metode Pengumpulan Data}

Untuk mendapatkan data yang diperlukan dalam penelitian, maka penulis menggunakan beberapa metode sebagai berikut:

1. Observasi (Pengamatan) 
Metode observasi dilakukan untuk pengamatan dan penelitian secara langsung pada PT. Lintasindo Dharma Sakti Jakarta, dengan tujuan melakukan observasi mengenai sistem berjalan pengiriman barang di PT. Lintasindo Dharma Sakti Jakarta, Penulis mengamati tentang proses pengolahan data pengiriman barang, mengamati kegiatan pencatatan pengiriman dari tarif, alamat, dan muatan barang pengiriman, sehingga mengetahui kelemahan sistem yang ada.

2. Wawancara

Penulis melakukan metode ini untuk memenuhi informasi penelitian, sehingga berusaha mendapatkan data dengan cara bertanya langsung kepada bapak Junaldi sebagai administrasi gudang barang pada PT. Lintasindo Dhrma Sakti Jakarta. Hasil dari wawancara penulis menafsirkan dan mengembangkan informasi yang berkaitan dengan masalah yang akan disusun.

3. Studi Pustaka

Kegiatan ini dilakukan untuk mendapatkan gambaran yang menyeluruh tentang apa yang sudah dikerjakan orang lain dan bagaimana orang mengerjakannya, sumber pada studi pustaka ini diperoleh dari membaca buku, artikel ilmiah serta jurnal penelitian sejenis yang pernah dilakukan sebelumnya.

\section{B. Metode Pengembangan Sistem}

Pada penelitian ini model pengembangan sistem yang akan digunakan yaitu menggunakan metode Rapid Application Development (RAD). Rapid Aplication Development (RAD) adalah sebuah model proses perkembangan perangkat lunak (Software) sekuensial linier yang menekankan pada siklus perkembangan yang cepat dengan menggunakan pendekatan konstruksi berbasis komponen. Sehingga apabila kebutuhan dipahami dengan baik, model ini akan membentuk sistem fungsional yang utuh serta dapat diselesaikan dalam waktu kira-kira 60 - 90 hari (Pressman, 2002). Model ini dikembangkan oleh James Martin dengan tahapan sebagai berikut (Kendall \& Kendall, 2010):

1. Fase Menentukan Syarat-Syarat

Pada tahap ini dilakukan penentuan tujuan dan syarat-syarat informasi, yaitu dengan melakukan analisa kebutuhan masalah untuk pembuatan sistem informasi jasa pengiriman barang, menentukan tujuan dibuatnya sistem, lalu menentukan syaratsyarat yang diperlukan untuk membuat sistem informasi tersebut.

2. Fase Perancangan

Pada tahap ini dilakukan perancangan proses-proses yang akan terjadi dalam sistem dan perancangan antar muka. Alat bantu yang digunakan adalah menggunakan ERD (Entity Relationship Diagram) dan UML (Unified Modelling Language) Tujuan pada tahapan ini adalah melakukan proses desain dan melakukan perbaikan-perbaikan apabila masih terdapat ketidaksesuaian desain dari sistem yang dibangun.

\section{Fase Konstruksi}

Proses pada tahap ini akan dilakukan dalam bentuk coding program terhadap rancangan-rancangan yang telah didefinisikan. Bahasa pemrograman yang digunakan adalah Java Script, dan MySQL untuk databasenya.

4. Fase Pelaksanaan

Pada tahap ini dilakukan pengujian terhadap sistem. Tahap pengujian (testing) akan dilakukan tes terhadap program yang sudah dibuat. Pengetesan dilakukan mulai dari pengetesan terhadap modulmodul yang ada pada program dan kemudian dilakukan black box testing. Cara pengujian ini dilakukan dengan menjalankan sistem informasi pengiriman barang, untuk melihat apakah jalannya sistem sudah sesuai yang diharapkan.

\section{HASIL DAN PEMBAHASAN}

Berikut adalah langkah-langkah yang dilakukan pada metode pengembangan sistem menggunakan Rapid Application Development (RAD) yaitu sebagai berikut:

\section{A. Fase Perencanaan Syarat - Syarat}

Pada tahap ini dilakukan analisa kebutuhan masalah untuk pembuatan aplikasi, mengedintifikasi permasalahan, dan memberikan solusi terhadap permasalahan yang dihadapi.

1. Proses Bisnis Sistem Berjalan

Dalam kegiatan pengiriman PT. Lintasindo Dharma Sakti diawali dari Pelanggan atau biasa disebut pengirim yang menyerahkan barang serta alamat pengiriman kepada admin bagian gudang. Kemudian barang diserahkan dahulu kepada pegawai untuk ditimbang, dari informasi yang admin dapatkan admin akan memperoleh info pembayaran setelah itu dibuatlah 4 rangkap stt (surat tanda terima) oleh admin bagian gudang, lembar pertama berwarna putih untuk pengirim sebagai bukti pengiriman, lembar kuning untuk pengarsipan ke dalam buku laporan pengiriman yang setiap akhir bulannya dilakukan pencatatatan untuk laporan yang akan diserahkan kepada kepala gudang, lembar ketiga dan empat sebagai surat jalan yang akan diserahkan admin kepada kurir yaitu warna biru dan merah, warna biru akan diserahkan kurir ke penerima untuk ditanda tangani sebagai bukti penerimaan, kemudian warna merah akan dikembalikan oleh kurir kepada admin gudang setelah kurir selesai melakukan pengiriman yang telah ditanda tangani oleh penerima sebagai arsip kurir ke dalam daftar muatan. Setelah pencatatan bulanan dibuat pada 
buku laporan pengiriman dan daftar muatan, maka akan diserahkan setiap bulannya kepada kepala gudang sebagai bukti transaksi pengiriman dan bukti pengiriman yang akan di lakukan pngecekan dan penilaian oleh kepala gudang. Setelah laporan disetujui, kepala gudang mengembalikan buku laporan dan daftar muatan kembali kepada admin bagian gudang untuk disimpan ke arsip gudang pengiriman barang.

Berikut adalah penggambaran proses bisnis sistem berjalan menggunakan Activity Diagram.

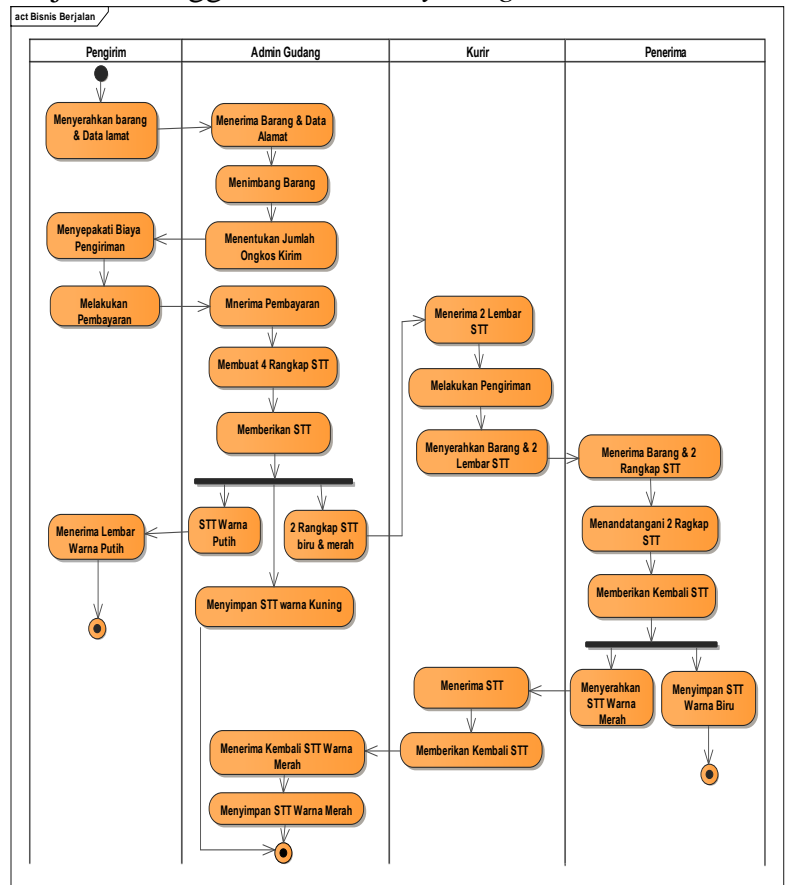

Sumber: (Nilawati, Sulastri, \& Yuningsih, 2020)

Gambar 1. Activity diagram Proses Bisnis Sistem Berjalan

Sedangkan untuk penggamb proses laporan pengiriman sistem berjalan dapat dilihat pada activity diagram berikut:

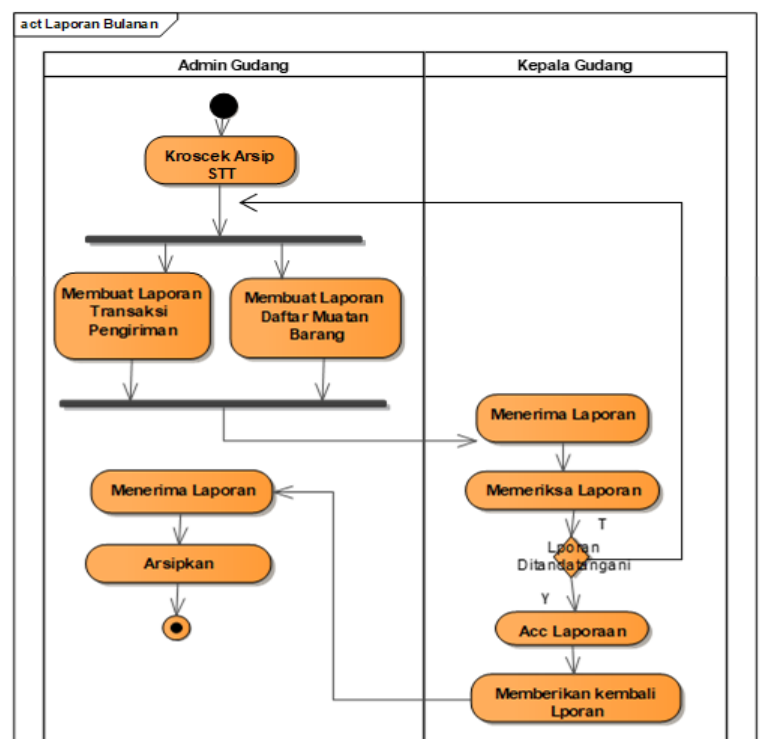

Sumber: (Nilawati, Sulastri, \& Yuningsih, 2020)

Gambar 2. Activity Diagram Proses Laporan Pengiriman Sistem Berjalan

2. Analisa Kebutuhan Software

Analisa kebutuhan software merupakan suatu kegiatan untuk mengetahui, merancang mengidentifikasi permasalahan-permasalahan yang terdapat pada sistem dan menentukan kebutuhankebutuhan dari sistem yang akan dibangun. Analisa kebutuhan sistem sangat dibutuhkan pada proses bisnis di PT. Lintasindo Dharma Sakti jakarta, sistem yang digunakan harus sesuai dengan kebutuhan yang ada pada PT. Lintasindo Dharma Sakti jakarta, terdapat kebutuhan dalam mengelola data pengiriman barang, nota pengiriman, dan laporan pengiriman. Program aplikasi yang dibuat hanya bisa dipakai oleh admin bagian gudang, tujuan pembuatan program aplikasi ini adalah untuk mempermudah dalam proses pengiriman barang dan penyimpanan data pengiriman.

Berikut ini spesifikasi rancangan Analisa Kebutuhan perangkat lunak dari sistem informasi jasa pengiriman barang, yang akan dibangun yang sesuai kebutuhan. Tujuan pembuatan program aplikasi ini adalah untuk mempermudah dalam proses pengiriman barang dan penyimpanan data pengiriman. Analisa Kebutuhan perangkat lunak informasi pengiriman barang diusulkan dengan beberapa prosedur diantaranya:

a. Admin dapat melakukan login ke sistem.

b. Admin dapat melihat informasi ongkos kirim.

c. Admin dapat mengelola master data.

d. Admin dapat mengelola daftar pelanggan

e. Admin dapat mengelola daftar kurir

f. Admin dapat mengelola transaksi pengiriman.

g. Admin dapat mengelola detail pengiriman.

h. Admin dapat mengelola laporan pengiriman barang.

i. Admin dapat mencetak atau menyimpan datadata.

j. Hanya Admin yang dapat mengelola daftar admin sebagai hak akses sistem.

k. Hanya Admin yang dapat melakukan logout dari sistem.

\section{B. Fase Perancangan}

Tahapan selanjutnya dalam RAD setelah menganalisis proses sistem bisnis yang berjalan adalah tahap perancangan sistem yang bertujuan untuk mengatasi permasalahan-permasalahan yang ada dan memberikan usulan rancangan sistem.

1. Perancangan Sistem

Berdasarkan analisa kebutuhan software, maka sistem yang akan dibuat digambarkan menggunakan Use Case Diagram sebagai berikut: 


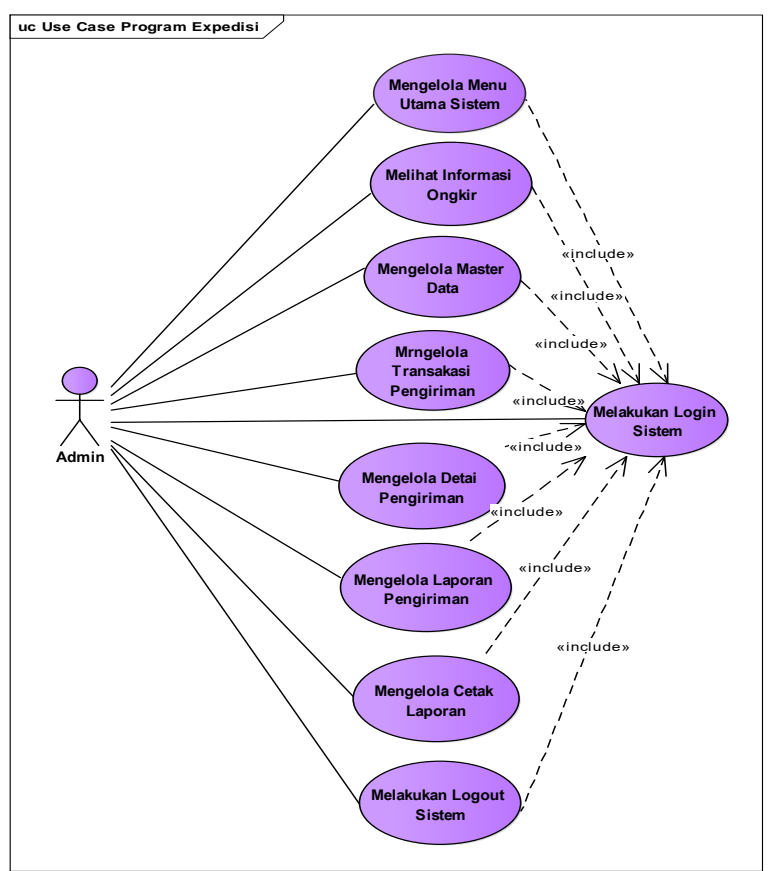

2. Perancangan Database

Basis data dalam aplikasi absensi ini diimplementasikan menggunakan Mysql yang terintegrasi dengan PHP. Perancangan database yang akan digunakan pada sistem informasi jasa pengiriman barang, yaitu dengan penggambaran Entity Relationship Diagram (ERD) sebagai berikut:

Sumber: (Nilawati, Sulastri, \& Yuningsih, 2020)

Gambar 3. Use Case Diagram Menu Sistem

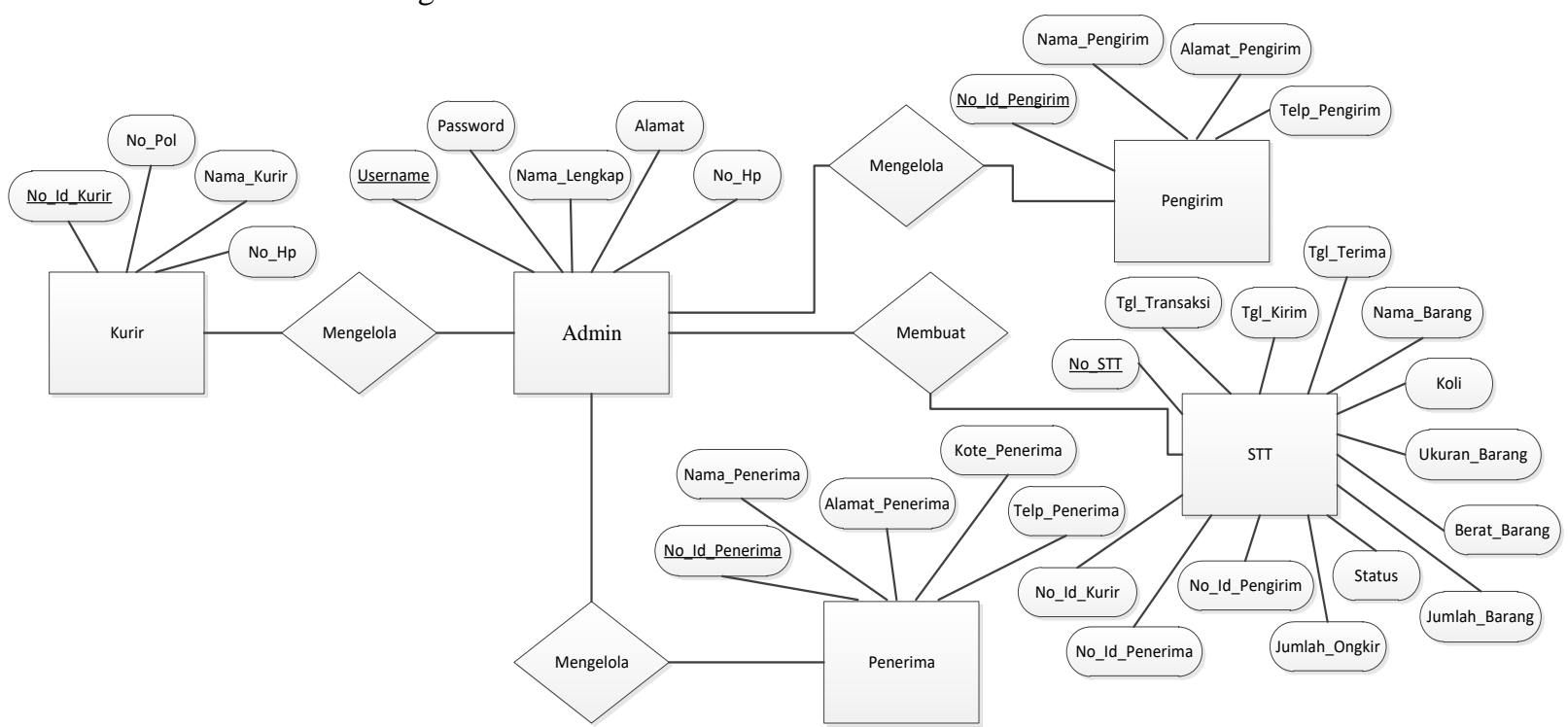

Sumber: (Nilawati, Sulastri, \& Yuningsih, 2020)

Gambar 4. Entity Relationship Diagram (ERD)

\section{Rancangan Tampilan (User Interface)}

User interface merupakan bentuk tampilan dalam bentuk grafis dan berhubungan langsung dengan pengguna, serta berfungsi untuk menghubungkan pengguna dengan sistem operasi sehingga komputer tersebut bisa berguna. Berikut ini adalah tampilan beberapa menu-menu program:

a. User Interface Login

Tampilan Login program ini merupakan tampilan halaman login admin yang sudah terdaftar dalam sistem serta berfungsi sebagai keamanan sistem.

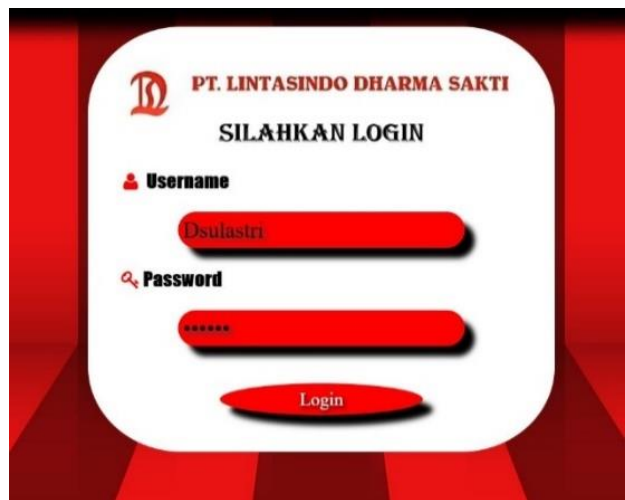

Sumber: (Nilawati, Sulastri, \& Yuningsih, 2020) Gambar 5. User Interface Form Login Admin 
b. User Interface Menu Utama

Tampilan Menu Utama program ini merupakan halaman tampil menu utama sistem.

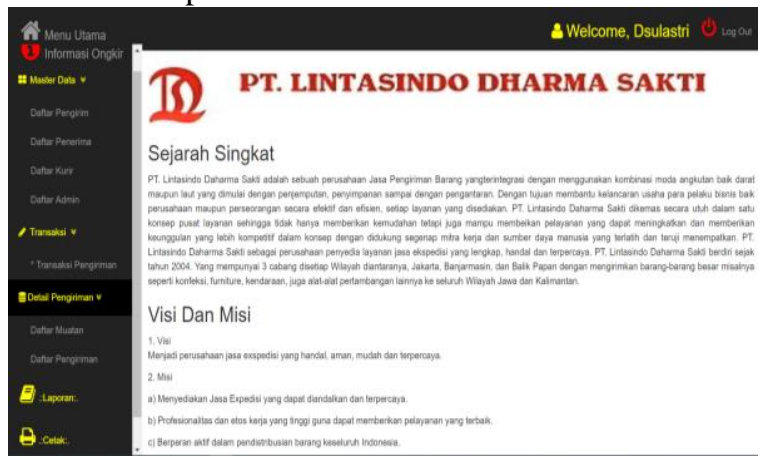

Sumber: (Nilawati, Sulastri, \& Yuningsih, 2020)

Gambar 6. User Interface Form Menu Utama

c. User Interface Informasi Ongkos Kirim

Tampilan program ini merupakan halaman informasi harga ongkos kirim jasa pengiriman barang.

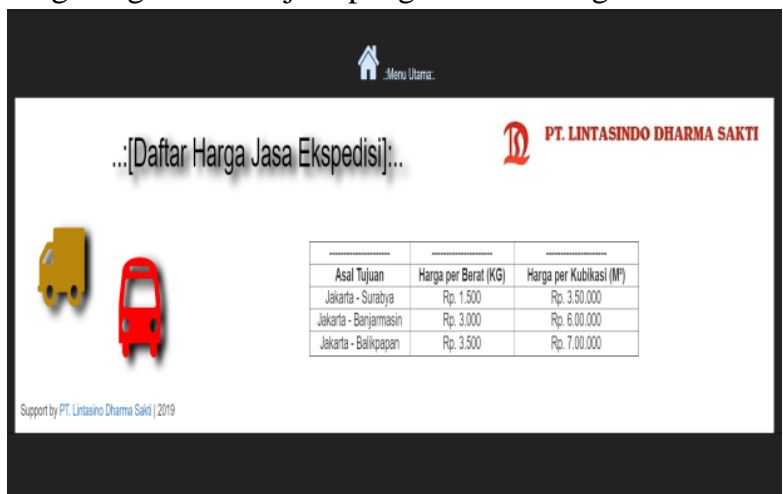

Sumber: (Nilawati, Sulastri, \& Yuningsih, 2020)

Gambar 7. User Interface Informasi Ongkos Kirim

d. User Interface Transaksi Pengiriman

Tampilan transaksi pengiriman ini merupakan halaman untuk menambahkan data transaksi pengiriman baru, admin terlebih dahulu memilih pengirim dan penerima kemudian proses. ..:[Pilih Penerima \& Pengirim]:.

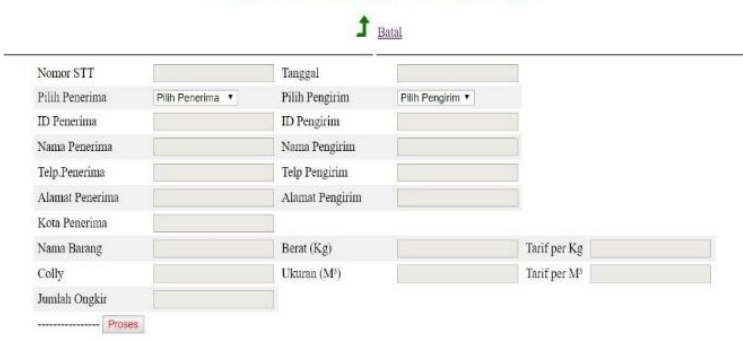

Sumber: (Nilawati, Sulastri, \& Yuningsih, 2020)

Gambar 8. User Interface Form Transaksi Pengiriman

Tampilan halaman form transaksi pengiriman jika sudah diisi akan seperti berikut:

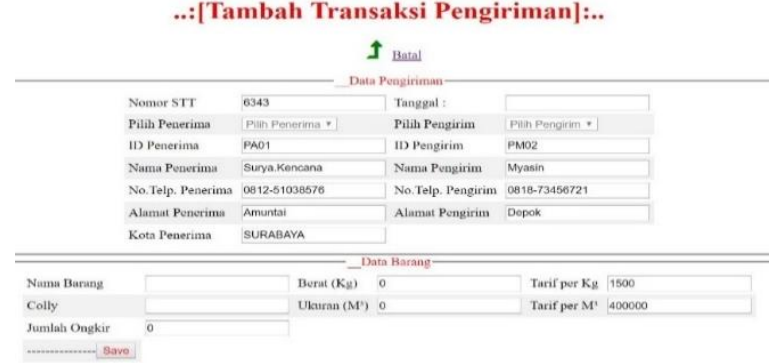

Sumber: (Nilawati, Sulastri, \& Yuningsih, 2020)

Gambar 9. User Interface Form Hasil Isian

Transaksi Pengiriman

Jika Admin ingin memasukan kembali transaksi pengiriman bisa langsung memilih tambah transaksi pengiriman, maka form transaksi pengiriman akan muncul kembali

d. User Interface Halaman Tampil dan Cetak Daftar Pengiriman

Tampilan program ini merupakan halaman tampil dan cetak daftar pengiriman.

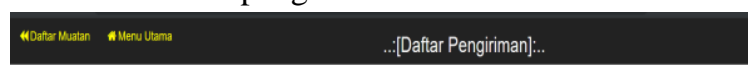

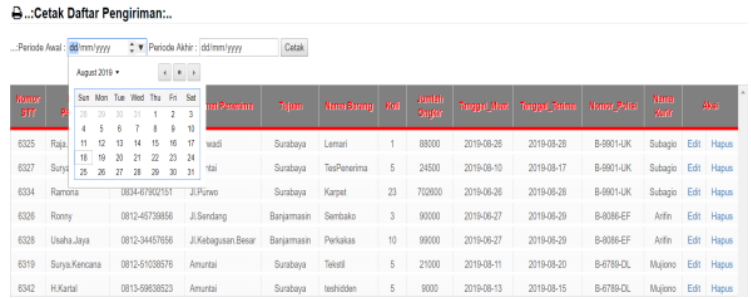

Sumber: (Nilawati, Sulastri, \& Yuningsih, 2020)

Gambar 10. User Interface Halaman Tampil dan Cetak Daftar Pengiriman

e. User Interface Halaman Cetak

Tampilan program ini merupakan halaman pilih cetak transaksi pengiriman berdasarkan STT Pengirim, cetak daftar muatan, atau cetak daftar pengiriman.

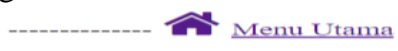

\section{..: PILIH CETAK:..}

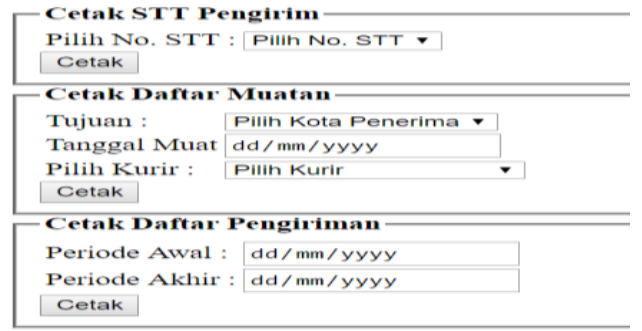

PT. Lintasindo Dharma Sakti | 2019

Sumber: (Nilawati, Sulastri, \& Yuningsih, 2020)

Gambar 11. User Interface Halaman Cetak 


\section{Fase Konstruksi}

Pada tahap ini pembangunan sistem informasi jasa pengiriman barang meliputi pemenuhan kebutuhan hardware (perangkat keras) dan Software (perangkat lunak) yang digunakan. Berikut ini adalah Spesifikasi Hardware dan Software yang dibutuhkan yaitu sebagai berikut:

Tabel 1. Spesifikasi Hardware dan Software

\begin{tabular}{lll}
\hline Kebutuhan & \multicolumn{2}{c}{ Keterangan } \\
\hline Sistem & Windows 7 Profesional \\
\hline Procesor & Pentium 4 & \\
\hline Ram & $2 \mathrm{~Gb}$ & \\
\hline Hardisk & $60 \mathrm{~GB}$ & \\
\hline Monitor & 14 Led & \\
\hline Keyboard & 108 Key & \\
\hline Mouse & Standar & aplikasi secara \\
\hline Printer & Dot Matrik & : Apache 3.2 \\
\hline Software & Kebutuhan menjalankan & \\
& local : & : MySQL
\end{tabular}

Sumber: (Nilawati, Sulastri, \& Yuningsih, 2020)

\section{Fase Pelaksanaan}

Pada tahap ini dilakukan pengujian terhadap sistem dan melakukan pengenalan terhadap sistem. Metode pengujian dengan pendekatan blackbox testing. Proses pengujian menggunakan blackbox testing merupakan metode untuk mengetahui apakah perangkat lunak berfungsi dengan benar atau tidak, dimana pada pengujian ini hanya dapat diketahui input dan ouputnya saja tanpa mengetahui detail struktur internal dari sistem yang akan di tes. Salah satu hasil pengujian blackbox testing dapat dilihat dalam tabel berikut.

Tabel 2. Hasil Pengujian Black Box Testing Form

\begin{tabular}{llll} 
& \multicolumn{2}{c}{ Login } & \\
\hline No. & \multicolumn{1}{c}{$\begin{array}{c}\text { Skenario } \\
\text { pengujian }\end{array}$} & $\begin{array}{c}\text { Hasil yang } \\
\text { diharapkan }\end{array}$ & Kesimpulan \\
\hline 1. & Username dan & Sistem akan & Valid \\
& Password & menolak akses & \\
tidak diisi & dan \\
kemudian klik & menampilkan & \\
tombol login & pesan \\
Test case: & "Data Tidak & \\
Username: & Boleh \\
(kosong) & Kosong!" & \\
\hline
\end{tabular}

\begin{tabular}{|c|c|c|c|}
\hline & $\begin{array}{l}\text { Password: } \\
\text { (kosong) }\end{array}$ & $\begin{array}{l}\text { Hasil } \\
\text { Pengujian: } \\
\text { Sesuai harapan }\end{array}$ & \\
\hline 2. & $\begin{array}{l}\text { Mengetikkan } \\
\text { Username dan } \\
\text { Password } \\
\text { tidak diisi } \\
\text { atau kosong } \\
\text { kemudian klik } \\
\text { login } \\
\text { Test case: } \\
\text { Username: } \\
\text { ABC } \\
\text { Password: } \\
\text { (kosong) }\end{array}$ & $\begin{array}{l}\text { Sistem akan } \\
\text { menolak akses } \\
\text { dan } \\
\text { menampilkan } \\
\text { pesan "Data } \\
\text { Tidak Boleh } \\
\text { Kosong!" } \\
\text { Hasil } \\
\text { Pengujian: } \\
\text { Sesuai harapan }\end{array}$ & Valid \\
\hline 3. & $\begin{array}{l}\text { Username } \\
\text { tidak di isi } \\
\text { (kosong) dan } \\
\text { Password } \\
\text { diisi kemudian } \\
\text { klik login } \\
\text { Test case: } \\
\text { Username: } \\
\text { (kosong) } \\
\text { Password: } \\
\text { admin }\end{array}$ & $\begin{array}{l}\text { Sistem akan } \\
\text { menolak } \\
\text { Akses dan } \\
\text { menampilkan } \\
\text { pesan } \\
\text { "Data Tidak } \\
\text { Boleh } \\
\text { Kosong!" } \\
\text { Hasil } \\
\text { Pengujian: } \\
\text { Sesuai harapan }\end{array}$ & Valid \\
\hline 4. & $\begin{array}{l}\text { Mengetikkan } \\
\text { salah satu } \\
\text { kondisi salah } \\
\text { pada } \\
\text { username atau } \\
\text { password } \\
\text { kemudian klik } \\
\text { login. } \\
\text { Test case: } \\
\text { Username: } \\
\text { ABC } \\
\text { (salah) } \\
\text { Password: } \\
\text { 12345 } \\
\text { (salah) }\end{array}$ & $\begin{array}{l}\text { Sistem akan } \\
\text { menolak } \\
\text { akses } \\
\text { menampilkan } \\
\text { pesan } \\
\text { "Maaf } \\
\text { Username } \\
\text { Atau } \\
\text { Password } \\
\text { Salah" } \\
\text { Hasil } \\
\text { Pengujian: } \\
\text { Sesuai } \\
\text { harapan }\end{array}$ & Valid \\
\hline
\end{tabular}

Sumber: (Nilawati, Sulastri, \& Yuningsih, 2020)

\section{KESIMPULAN}

Setelah melakukan analisis dan penerapan sistem yang dilanjutkan dengan pengujian sistem, maka dari hasil penerapan dapat disimpulkan bahwa sistem ini dapat mempermudah admin bagian gudang, untuk membuat daftar pengiriman barang, mudah mendata daftar kurir, daftar penerima, dan daftar pengirim. Selain itu dengan adanya sistem ini, admin dapat dengan mudah mengontrol pengiriman barang secara efektif dan efisien. Semua data yang dimasukan oleh admin terkelola dengan baik dalam database lokal, yaitu database program yang sewaktu-waktu dapat diambil datanya apabila diperlukan. 


\section{REFERENSI}

Irawan, Y., Mustafid, M., \& Sugiharto, A. (2014). Sistem Informasi Perpustakaan Berbasis Web Application. Jurnal Sistem Informasi Bisnis, 1(2), 69-72.

Kendall, K. E., \& Kendall, J. E. (2010). Analisis dan Perancangan Sistem. Jakarta: PT Indeks.

Kirlyana, B., \& Rosyida, S. (2016). Sistem Informasi Penjualan Sepatu Handmade Berbasis Web. Information Management for Educators and Professionals, 1(1), 22-31.

Kosasi, S. (2015). Penerapan Rapid Application Development Dalam Sistem Perniagaan Elektronik Furniture. Citec Journal, 2(4), 265276.

Kosasi, S., \& Yuliani, I. D. A. E. (2015). Penerapan Rapid Application Development Pada Sistem Penjualan Sepeda Online. Simetris, 6(1), 27 36. Retrieved from http://jurnal.umk.ac.id/index.php/simet/article/ view/234

Nilawati, L., Sulastri, D., \& Yuningsih, Y. (2020). Laporan Akhir Penelitian: Penerapan Model Rapid Application Development Pada Perancangan Sistem Informasi Jasa Pengiriman Barang.

Noertjahyana, A. (2002). Studi Analisis Rapid Aplication Development Sebagai Salah Satu Alternatif Metode Pengembangan Perangkat Lunak. Jurnal Informatika, 3(2), 74-79.

Pratama, F. A., Nurdiawan, O., \& Pramudita, R. (2019). Sistem Informasi Monitoring Pajak Bumi Bangunan menggunakan Metode Rapid Application Development. Bina Insani ICT Journal, 6(2), 23-34.

Pressman, R. S. (2002). Rekayasa Perangkat Lunak Pendekatan Praktisi (Buku Satu). Yogyakarta: Andi.
Ramdhani, M. A., \& Rusmana, R. (2019). Perancangan Sistem Proyek Pertunjukan Berbasis Web Menggunakan Metode RAD. INFORMASI (Jurnal Informatika dan Sistem Informasi), XI(2), 33-50.

Ratnawati, \& Gustini, L. (2019). Pengembangan Aplikasi Akuntansi Pendapatan Jasa Perusahaan Ekspedisi Menggunakan Metode Rapid Application Development. Journal Speed-Sentra Penelitian Engineeringdan Edukasi, 11(4), 35-42.

\section{PROFIL PENULIS}

Lala Nilawati, M.Kom. Menempuh pendidikan Sarjana (S1) di Sekolah Tinggi Manajemen Informatika dan Komputer Nusa Mandiri, Program Studi Sistem Informasi lulus tahun 2010, dan Program Magister (S2) Sekolah Tinggi Manajemen Informatika dan Komputer Nusa Mandiri, Program Studi Ilmu Komputer lulus tahun 2015. Saat ini aktif bekerja menjadi staff pengajar (dosen) di Universitas Bina Sarana Informatika.

Dedeh Sulastri, Menempuh pendidikan Diploma Tiga di Universitas Bina Sarana Informatika, lulusan program studi Sistem Informasi Akuntansi tahun 2019.

Yuyun Yuningsih, M.Kom. Menempuh pendidikan Sarjana (S1) di Sekolah Tinggi Manajemen Informatika dan Komputer Nusa Mandiri, Program Studi Sistem Informasi lulus tahun 2013, dan Program Magister (S2) Sekolah Tinggi Manajemen Informatika dan Komputer Nusa Mandiri, Program Studi Ilmu Komputer lulus tahun 2015. Saat ini aktif bekerja menjadi staff pengajar (dosen) di STMIK Nusa Mandiri. 